\title{
Resenhas
}

\section{Chutando a Escada: a estratégia do desenvolvimento em perspectiva histórica} Ha-Joon Chang São Paulo: Editora UN ESP, 2004.

A versão original desse livro foi publicada em inglês, em 2002, e foi traduzida para uma série de idiomas. Seu autor, Ha-Joon Chang, é um coreano, professor da Universidade de Cambridge, na Inglaterra, desde 1990, e diretor-adjunto do Departamento de Estudos sobre Desenvolvimento. Ha-Joon vem sendo considerado um líder da nova geração de economistas heterodoxos que tentam revitalizar os trabalhos e debates na área de desenvolvimento econômico

Em 2003, o livro, cujo título original em inglês é Kicking away the ladder: development strategy in historical perspective, foi o vencedor do Prêmio Gunnar Myrdal, dado pela EAEPE (European Association for Evolutionary Political Economy) para a melhor publicação.

Seu autor, Ha-Joon Chang, dividiu o Prêmio Leontief (Wassily Leontief Prize for Advancing the Frontiers of Economic Thought) de 2005, dado pela Universidade de Tufts, com Richard R. Nelson, professor da Universidade de Columbia. O Prêmio Leontief foi recebido pela sua contribuição para o estudo do desenvolvimento econômico de países pobres e pelos seus trabalhos tentando desvendar a problemática relação existente entre metas de desenvolvimento e uma economia globalizada.

O título do livro, Chutando a escada, faz referência a parte de uma frase de Friedrich List, economista alemão do século XIX (1789-1846), defensor do protecionismo à indústria nascente. Em seu trabalho, Ha-Joon afirma que os países em desenvolvimento estão sendo pressionados pe- los países desenvolvidos a adotar o que chamam de "boas políticas e boas instituições", capazes de promover o desenvolvimento econômico. As "boas políticas" seriam as recomendadas pelo Consenso de Washington, dentre elas podemos citar políticas macroeconômicas restritivas, liberalização comercial e financeira, privatização, e desregulamentação. As "boas instituições" seriam as existentes nos países desenvolvidos, principalmente nos anglo-saxões, por exemplo, a democracia, um poder judiciário e banco central independentes e uma forte proteção aos direitos de propriedade. Os argumentos utilizados são que "políticas e instituições boas" foram adotadas pelos países desenvolvidos quando estavam em processo de desenvolvimento. Chang mostra que não faltam evidências históricas sugerindo o contrário.

O principal questionamento de seu trabalho é: "Como os países ricos enriqueceram de fato?” Esta pergunta é o título do primeiro capítulo do livro.

A obra é dividida em quatro capítulos. O primeiro é introdutório, discutindo o método de análise utilizado e os questionamentos do autor, antecipando também algumas conclusões finais do trabalho. O capítulo 2 aborda as chamadas políticas de ICT (políticas industrial, comercial e tecnológica). Segundo Chang, são as diferenças nestas políticas que, para ele, separam os países bem-sucedidos, em termos de desenvolvimento econômico, dos outros países, deixando claro que não nega a importância de outras políticas. O terceiro capítulo analisa um grande número de instituições. 
Ha-Joon afirma que (p. 25), "[...]Tanto quanto me é dado saber, este livro é o único que oferece informações em um espectro tão amplo de instituições, passando por um grande número de países". No último capítulo, intitulado "Lições para o presente", o autor tenta responder os seus questionamentos iniciais, dando algumas sugestões para os países em desenvolvimento.

Após a análise do desenvolvimento econômico sob um prisma histórico, Ha-Joon conclui que se os países desenvolvidos tivessem mesmo adotado as políticas que recomendam aos países em desenvolvimento, não seriam o que são hoje. Muitos deles, ao longo de sua trajetória de desenvolvimento, recorreram a políticas comerciais e industriais protecionistas, atualmente consideradas políticas "ruins". Além disso, no século XIX e início do século XX, antes de se tornarem países desenvolvidos, possuíam poucas das instituições que agora recomendam aos países em desenvolvimento. Em outras palavras, os países desenvolvidos, pregando políticas ortodoxas, estariam hoje "chutando a escada" para que os países em desenvolvimento não consigam seguir os mesmos caminhos trilhados por eles para se desenvolver.

O ponto alto do livro são os dados históricos que questionam determinados mitos em relação aos países desenvolvidos. Por exemplo, na tabela 2.1 (pág. 36), fica claro que, de 1820 até 1931, os EUA e alguns outros países hoje desenvolvidos adotaram políticas altamente protecionistas para defender a sua indústria nascente, mas eles alegam que fizeram o contrário: que liberalizaram seus mercados. Em um trecho do livro (pág. 66), que analisa as políticas de ICT adotadas pela Alemanha, menciona-se a utilização de espio- nagem industrial patrocinada pelo Estado e a cooptação de trabalhadores da Inglaterra, práticas que seriam consideradas "ruins" nos dias de hoje. Em uma outra parte do livro (págs. 12736), Ha-Joon demonstra que, nos países desenvolvidos, a democracia, durante muito tempo, não foi muito democrática, porque excluía pessoas por renda, sexo, cor... Existia também compra de votos, fraude eleitoral e corrupção. Segundo o autor, os países em desenvolvimento, nas fases iniciais da democracia, não tiveram tantos problemas como os países desenvolvidos.

O livro é de leitura fácil, com abundância de dados históricos não só de países tradicionalmente analisados como EUA, Alemanha, França, Grã-Bretanha e Japão, mas também de países menores, como a Bélgica, Suíça, Holanda, etc. Apresenta, assim como em outros livros do mesmo autor, uma visão crítica em relação ao papel do Estado no desenvolvimento econômico e em relação às políticas recomendadas aos países em desenvolvimento pelos órgãos de fomento internacional como o Banco Mundial e o Fundo Monetário Internacional.

É um trabalho original, recomendado para leitura a economistas e pessoas com diversas áreas de formação, inclusive a formuladores de políticas públicas. Contém inúmeras referências bibliográficas e estimula a repensar as estratégias de desenvolvimento econômico que vêm sendo adotadas pelos países pobres e em desenvolvimento.

Carmen Augusta Varela

Professora da Escola de Administração

de Empresas de São Paulo

da Fundação Getúlio Vargas

\section{Freakonomics: o lado oculto e inesperado de tudo que nos afeta}

Steven D. Levitt e Stephen J. Dubner Rio de Janeiro: Elsevier, 2005.

Em um tempo em que estudantes e profissionais queixam-se do elevado grau técnico das discussões acadêmicas em Economia, surge um livro que busca, de maneira simples e irreverente, revelar as diversas possibilidades de aplicação da teoria econômica. É principalmente por esta razão que o lançamento do livro Freakonomics: o lado oculto e inesperado de tudo que nos afe- ta, de autoria de Steven D. Levitt e Stephen J. Dubner deve ser saudado.

Recentemente, ocorreram esforços semelhantes ao dos autores. Por exemplo, o livro Sexo, drogas e E conomia, de Diane Coyle (São Paulo: Futura, 2003), equivale a uma tentativa de apresentar uma introdução didática a temas pouco convencionais vistos sob o prisma da Ciência 